\title{
Physiological Parameters of Soybean Under Different Intensities of Artificial Light
}

\author{
Lucas Aparecido Manzani Lisboa ${ }^{1,2}$, Amanda Stelutti $^{1}$, Karla Caroline Santana Lima $^{1}$, \\ Guilherme Bandeca Rafachinho ${ }^{1}$, Renata Alari Chedid ${ }^{1}$, Jeruska Azevedo Moreira Brenha ${ }^{1}$, \\ Pedro Henrique de Conde de Almeida ${ }^{1}$, Nubia Priscila de Oliveira Crispim ${ }^{1}$, Gabriel Banos Rodrigues ${ }^{1}$ \\ $\&$ Paulo Alexandre Monteiro de Figueiredo ${ }^{2}$ \\ ${ }^{1}$ Educational Foundation of Andradina, São Paulo, Brazil \\ ${ }^{2}$ College of Agricultural and Technological Sciences, São Paulo State University, Campus of Dracena, Brazil \\ Correspondence: Lucas Aparecido Manzani Lisboa, Educational Foundation of Andradina, São Paulo, Brazil. \\ E-mail: lucas.lisboa@unesp.br
}

Received: March 10, 2019

Accepted: April 15, $2019 \quad$ Online Published: June 15, 2019

doi:10.5539/jas.v11n8p188

URL: https://doi.org/10.5539/jas.v11n8p188

\begin{abstract}
Luminosity and temperature are factors that directly act in photosynthetic process, in which the elevation of the light intensity may provoke reduction in the assimilation of carbon, impairing the development of the soybean culture. This work aimed to know physiological parameters of soybean (Glycine max L. Merr.) under different intensities of artificial light. The experiment was carried out in randomized blocks, in a factorial scheme $2 \times 5$, being two soybean cultivars (Potência and NS6700) and five densities of light: 0 (control), 500, 1000, 1500 and $2000 \mu \mathrm{mol} \mathrm{m} \mathrm{m}^{-2} \mathrm{~s}^{-1}$ of photosynthetically active radiation (PAR) provided by LED bulbs, with 4 repetitions, in total of 40 plots. The following variables were set: rate of $\mathrm{CO}_{2}$ assimilation (A), transpiration (E), stomatal conductance (gs), inner $\mathrm{CO}_{2}$ concentration in the substomatic chamber (Ci) and water use efficiency (WUE) in which a portable device of gas exchange was used (Infra-Red Gas Analyzer-IRGA, marca ADC BioScientific Ltd, modelo LC-Pro). Seedlings of soybean positively responded under different intensities of artificial light till reach the maximum saturation point between 1400 and $1600 \mu \mathrm{mol} \mathrm{m}^{-1} \mathrm{~s}^{-1}$ of light, which promoted a better rate of $\mathrm{A}, \mathrm{Ci}$ andWUE. $\mathrm{E}$ and gs presented positive linear responses by increasing the intensity of artificial light. The ideal light intensity to the use of Infra-Red Gas Analyzer-IRGA between 1400 and $1600 \mu \mathrm{mol} \mathrm{m}^{-1} \mathrm{~s}^{-1}$ to the soybean culture.
\end{abstract}

Keywords: Glycine max, luminosity, $\mathrm{CO}_{2}$ assimilation, photosynthesis rate

\section{Introduction}

Soybean (Glycine max (L.) Merrill) has been the most cultivated segment of agrarian activity in Brazil due to the development of technologies in its production systems, which allows its cultivation throughout the country. Besides, soybean present a good adaptation to Brazilian lands, once they present good conditions to its growth, as temperature and luminosity.

Light is the primary source of energy regarding photosynthesis and morpho-genetics phenomenon, also, light is one of the main factors that influences on vegetal growth and development. By elevating the availability of light, it may occurs the intensification or even the reduction of photosynthetic activity thought the photo-inhibition entailed by the excess of light, depending on the vegetable specie (Xiong et al., 2017; Rockwell \& Holbrook, 2017). Light intensity and temperature may influences on photosynthesis process and contribute to reduction of $\mathrm{CO}_{2}$ absorption, which, consequently, impairs the growth of plants (Araújo \& Deminicis, 2009).

Plants submitted to average light present lower photosynthetic rate, entailing lower values of transpiration as compared to plants exposed to more intense light, therefore, as the light intensity decrease, the lost of water to the environment also decay, as well as the transpiration rate (Vieira et al., 2015). This shows the importance of light in plant's physiological process, once it acts in the activation of enzymes regarding carbon fixation and in the control of stomata cleft (Teixeira et al., 2015; Bellasio et al., 2017; Li et al., 2017).

The equilibrium in the levels of light intensity and its duration is an important tool to know the different responses of plants under light stress. Plants submitted to direct radiation of low intensity are more efficient in 
their photosynthesis, since the process is gradually commenced and did not impair the electron's ways through the photo-systems, however, as the intensity of photons increases over the leaves, plants present a higher photosynthesis rate with a lower efficient use of water and assimilation of $\mathrm{CO}_{2}$, once these parameter are harmed by saturating electrons in photosynthetic system (Taiz \& Zeiger, 2013).

It is worth noting that when the soybean is undergoing nutritional stress, the reactions processes in the photosynthesis and diffusion of $\mathrm{CO}_{2}$ through the stomata and mesophyll act as co-regulators at the point of light compensation, while an increase occurs in the rate of breathing as reported by Singh and Reddy (2018). In this way, it is important to know the response mechanisms that leguminous plants act when they are exposed to quality and light intensities, as they can also suffer from competition with weeds for light, nutrients and water (Lisboa et al. 2018). With an exposure that leads to overlapping, an action of Gibberellins (GAs) and auxin [indole-3-acetic acid (IAA)] play important roles in mediating adaptive responses to plant shading (Yang et al., 2018). This worked aimed to know physiological parameters of soybean under different intensities of artificial light.

\section{Material and Methods}

The experiment was carried out in November 2018, at Integrated College Stella Maris, in Andradina, São Paulo State, Brazil. The experiment was carried out in randomized blocks, in a factorial scheme of $2 \times 5$, being two soybean cultivars (Potência and NS6700) and five densities of light: 0 (control), 500, 1000, 1500 and $2000 \mu \mathrm{mol}$ $\mathrm{m}^{-2} \mathrm{~s}^{-1}$ of photosynthetically active radiation (PAR) provided by LED bulbs, with 4 repetitions were, in total of 40 plots.

Vases, with the capacity of $7 \mathrm{dm}^{3}$, were filled with soil obtained from the $0-0.3 \mathrm{~m}$-layer. The soil was classified as Hidroferric Red Latosol (Embrapa, 2013) and presented the following chemical attributes (Table 1):

Table 1. Chemical attributes of soil at the moment of experiment placing

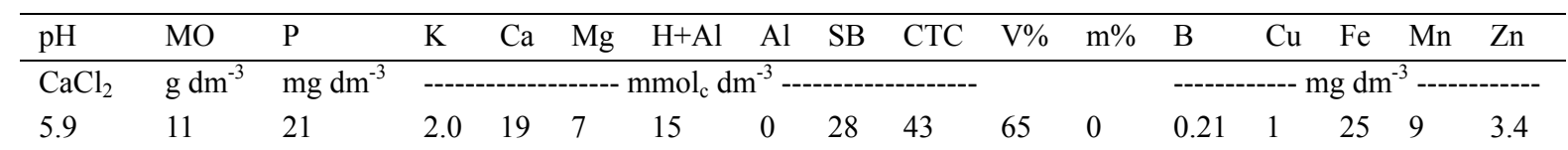

Note. SB: Sum of bases; V\%: Saturation per bases; m\%: Saturation per aluminum.

Soil was fertilized as the needs of soybean culture, according to Raij et al. (1996). During the experiment, all the plots were watered till reach the field capacity (Casaroli \& Lier, 2008), and culture treatments were done.

At the V4 development stage, the following parameter were set: rate of $\mathrm{CO}_{2}$ assimilation $\left(\mathrm{A}-\mu \mathrm{mol} \mathrm{CO}_{2} \mathrm{~m}^{-2} \mathrm{~s}^{-1}\right)$; transpiration (E-mmol $\mathrm{H}_{2} \mathrm{O} \mathrm{m}^{-2} \mathrm{~s}^{-1}$ ); stomatal conductance (gs-mol $\mathrm{H}_{2} \mathrm{O} \mathrm{m}^{-2} \mathrm{~s}^{-1}$ ); inner $\mathrm{CO}_{2}$ concentration in the substomatic chamber $\left(\mathrm{Ci}-\mu \mathrm{mol} \mathrm{mol}^{-1}\right)$, with $380 \mathrm{ppm}$ of $\mathrm{CO}_{2}$, under $28{ }^{\circ} \mathrm{C}$ temperature of chamber, a portable device of gas exchange was used (Infra-Red Gas Analyzer-IRGA, ADC BioScientific Ltd, modelo LC-Pro); and water use efficiency (WUE-A/E).

All variables were submitted to the $F$ test $(p<0.05)$ and analysis of regression were applied to the intensities of artificial light, in which their standards were tested: linear, quadratic and cubic. Soybean cultivars were submitted to Tukey test, at 5\% probability (Banzatto \& Kronka, 2013). Statistic program Assistat 7.7 was used (Silva \& Azevedo, 2016).

\section{Results}

Potência cultivar displayed the highest rate of $\mathrm{CO}_{2}$ assimilation, 21\% bigger than NS6700 (Table 2). 
Table 2. Average values of rate of $\mathrm{CO}_{2}$ assimilation (A- $\mu \mathrm{mol} \mathrm{CO} \mathrm{CO}_{2}^{-2} \mathrm{~s}^{-1}$ ); transpiration (E-mmol $\mathrm{H}_{2} \mathrm{O} \mathrm{m}^{-2} \mathrm{~s}^{-1}$ ); stomatal conductance (GS-mol $\left.\mathrm{H}_{2} \mathrm{O} \mathrm{m}^{-2} \mathrm{~s}^{-1}\right)$; inner $\mathrm{CO}_{2}$ concentration in the substomatic chamber $\left(\mathrm{Ci}-\mu \mathrm{mol} \mathrm{mol}^{-1}\right)$; water use efficiency (WUE) of soybean under different intensities of artificial light

\begin{tabular}{llllll}
\hline Cultivar (C) & A & E & gs & Ci & WUE \\
\hline Potência & $7.75 \mathrm{a}$ & $4.24 \mathrm{a}$ & $0.24 \mathrm{a}$ & $306.88 \mathrm{a}$ & $1.77 \mathrm{a}$ \\
NS6700 & $6.12 \mathrm{~b}$ & $3.56 \mathrm{~b}$ & $0.17 \mathrm{~b}$ & $304.05 \mathrm{a}$ & $1.61 \mathrm{~b}$ \\
CV $(\%)$ & 19.68 & 15.17 & 22.85 & 9.04 & 33.29 \\
Cultivar (C) & $85.45^{* *}$ & $80.38^{* *}$ & $120.39 * *$ & $0.63 \mathrm{~ns}$ & $4.78^{*}$ \\
Radiation (R) & $548.31^{* *}$ & $121.90^{* *}$ & $28.29 * *$ & $152.31^{* *}$ & $207.99^{* *}$ \\
C $\times$ R & $11.95^{* *}$ & $0,24 \mathrm{~ns}$ & $1.13 \mathrm{~ns}$ & $4.21^{* *}$ & $4.88^{* *}$ \\
\hline
\end{tabular}

Note. MSD: Minimum significant difference. CV: Coefficient of variation. OM: Overall mean. F: value of $\mathrm{F}$ calculated in the analysis of variance; $n s p=0.05 ; * 0.01 \leq p<0.05 ; * * p<0.01$. The averages in the column followed by the same letter do not differ statistically from each other. The Tukey test was applied at $5 \%$ probability level.

Again, Potência highlights with the greater leaf transpiration, with a 16\%-rate, as well as stomatal conductance, which present values around 30\% higher in Potência cultivar. No difference between Potência and NS6700 were observed regarding inner $\mathrm{CO}_{2}$ concentration in the substomatic chamber. Potência presented a higher efficient use of water with a difference around $9 \%$ as compared to NS6700. By considering light intensities over soybean cultivars, both presented quadratic and linear responses (Table 3).

Table 3. Variance analysis of regression of soybean under different intensities of artificial light. Standards linearand quadratic

\begin{tabular}{llllllll}
\hline \multicolumn{7}{c}{ Middle Square } \\
\hline Cultivar & FV & GL & A & E & GS & Ci & EUW \\
\hline \multirow{3}{*}{ Potência } & Radiation & 4 & 1911.1148 & 90.0987 & 0.1690 & 79273.5744 & 61.7382 \\
& Residue & 116 & 3.0952 & 0.4492 & 0.0034 & 1355.5129 & 0.5546 \\
& Regression & 1 & $\mathrm{Q}^{* *}$ & $\mathrm{~L}^{* *}$ & $\mathrm{~L}^{* *}$ & $\mathrm{Q}^{* *}$ & $\mathrm{Q}^{* *}$ \\
& Radiation & 4 & 1037.6705 & 75.7576 & 0.0811 & 113618.8148 & 75.6684 \\
& Residue & 116 & 1.4142 & 0.3513 & 0.0020 & 240.8550 & 0.1325 \\
& Regression & 1 & $\mathrm{Q}^{* *}$ & $\mathrm{~L}^{* *}$ & $\mathrm{~L}^{* *}$ & $\mathrm{Q}^{* *}$ & $\mathrm{Q}^{* *}$ \\
\hline
\end{tabular}

Note. Ns: $\mathrm{p} \geq 0.05 ;{ }^{*} 0.01 \leq \mathrm{p}<0.05 ; * * \mathrm{p}<0.01$. L: polynomial of 1st degree. Q: polynomial of 2nd degree. Rate of $\mathrm{CO}_{2}$ assimilation $\left(\mathrm{A}-\mu \mathrm{mol} \mathrm{CO} \mathrm{CO}_{2} \mathrm{~m}^{-2} \mathrm{~s}^{-1}\right.$ ); transpiration (E-mmol $\mathrm{H}_{2} \mathrm{O} \mathrm{m} \mathrm{m}^{-2} \mathrm{~s}^{-1}$ ); stomatal conductance (GS-mol $\left.\mathrm{H}_{2} \mathrm{O} \mathrm{m}^{-2} \mathrm{~s}^{-1}\right)$; inner $\mathrm{CO}_{2}$ concentration in the substomatic chamber $\left(\mathrm{Ci}-\mu \mathrm{mol} \mathrm{mol}^{-1}\right)$

It was found a quadratic response in the two soybean cultivars, in the parameter assimilation rate of $\mathrm{CO}_{2}$, with the increase of light intensity in levels between 1400 and $1600 \mu \mathrm{mol} \mathrm{m}^{-1} \mathrm{~s}^{-1}$ of light provided the highest maximum values (Figure 1); values above these maximum points may impair photosynthesis of plants. 


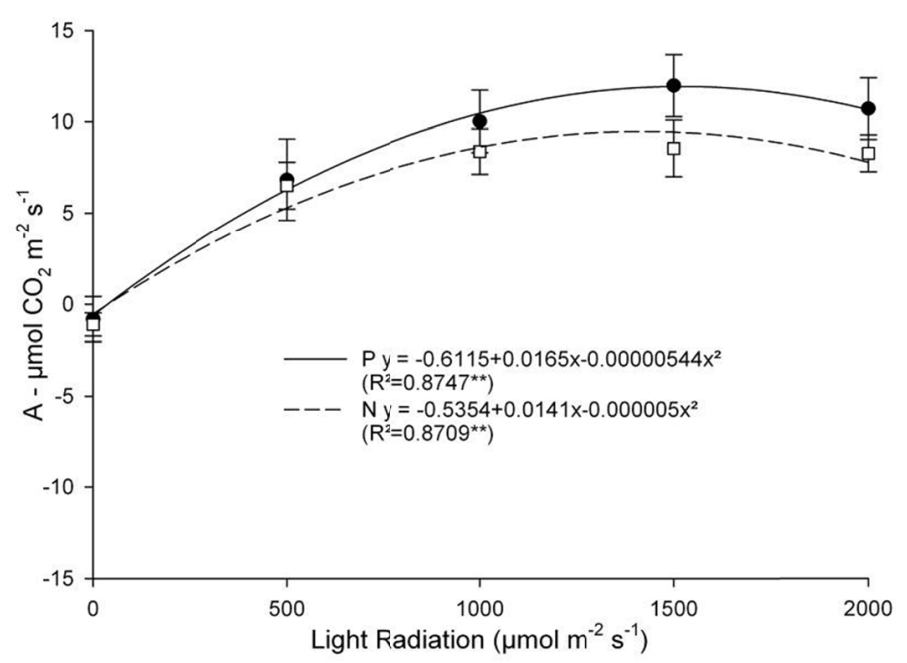

Figure 1. Rate of $\mathrm{CO}_{2}$ assimilation $\left(\mathrm{A}-\mu \mathrm{mol} \mathrm{CO}_{2} \mathrm{~m}^{-2} \mathrm{~s}^{-1}\right)$ of soybean leafs as submitted to different light intensities Note. $\mathrm{P}=$ Potência; $\mathrm{N}=\mathrm{NS} 6700$.

On the other hand, regarding Transpiration of leaf (E), cultivars displayed a positive linear response by increasing the light intensity, with an increase of approximately $14 \%$ in every $500 \mu \mathrm{mol} \mathrm{m}^{-1} \mathrm{~s}^{-1}$ of increased light (Figure 2).

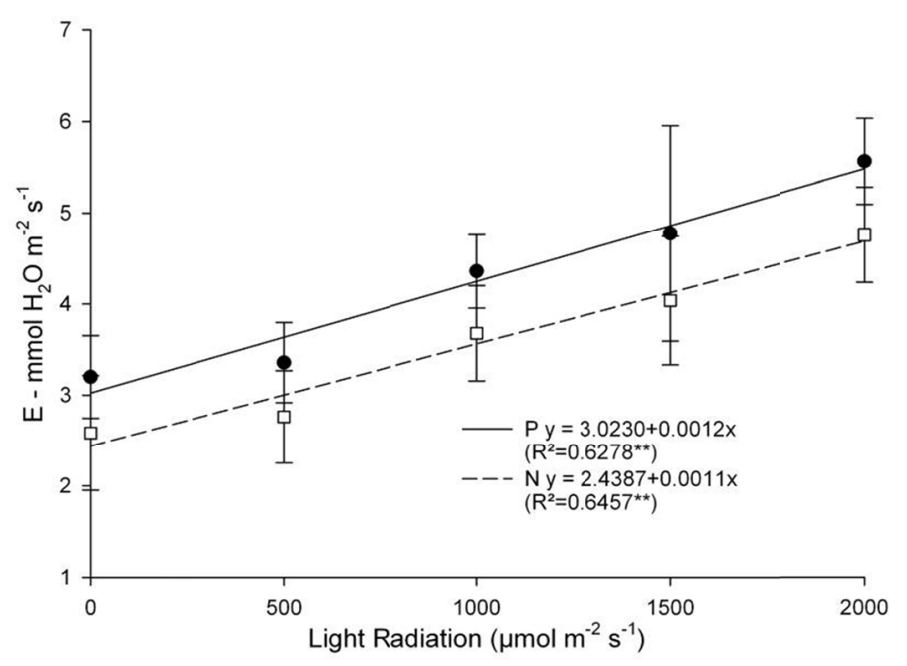

Figure 2. Transpiration (E) of soybean leaves as submitted to different light intensities

Note. $\mathrm{P}=$ Potência; $\mathrm{N}=\mathrm{NS} 6700$.

Stomatal conductance (gs) of both cultivars also presented a positive linear response with the elevation of the light intensity, with an increase of approximately $11 \%$ in every $500 \mu \mathrm{mol} \mathrm{m}^{-1} \mathrm{~s}^{-1}$ of increased light (Figure 3). 


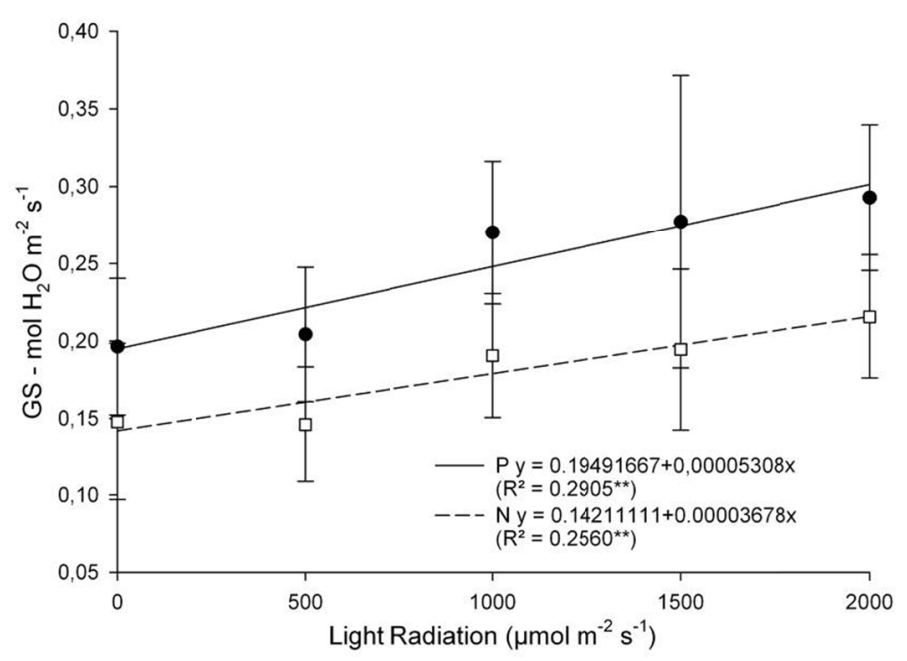

Figure 3. Stomatal conductance (gs) of soybean leaves as submitted to different light intensities

Note. $\mathrm{P}=$ Potência; $\mathrm{N}=\mathrm{NS} 6700$.

A quadratic negative response was observed regarding the inner concentration of $\mathrm{CO}_{2}$ in substomatic chamber (Ci) in soybean leafs as exposed to different intensities of artificial light between 1300 and $1420 \mu \mathrm{mol} \mathrm{m}^{-1} \mathrm{~s}^{-1}$ of light, however, intensities higher than these values promoted and elevation in this parameter (Figure 4).

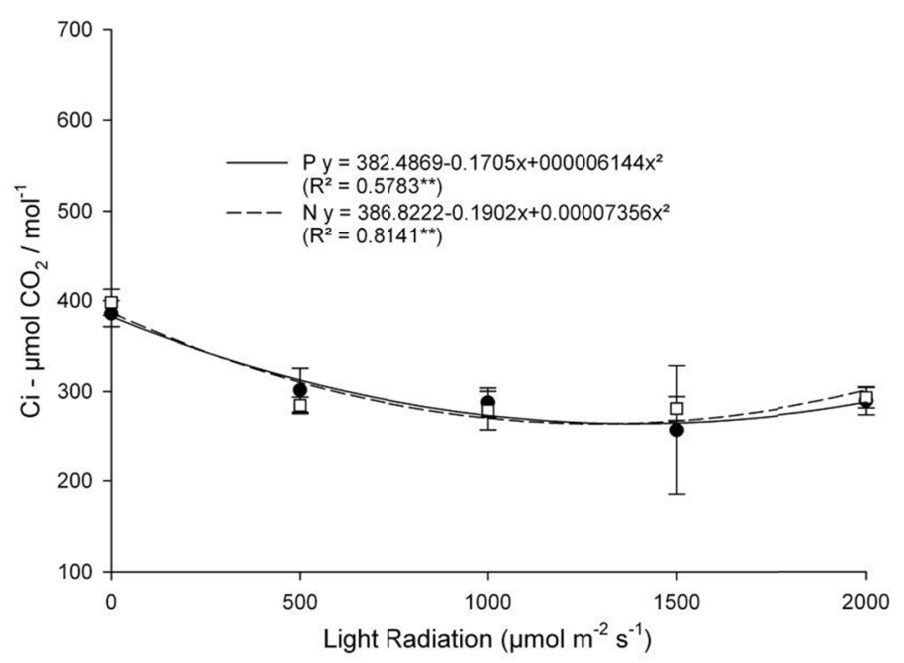

Figure 4. Inner concentration of $\mathrm{CO}_{2}$ in substomatic chamber (Ci) of soybean leaves as submitted to different light intensities

Note. $\mathrm{P}=$ Potência; $\mathrm{N}=\mathrm{NS} 6700$.

The parameter water use efficiency (WUE) of soybean presented quadratic positive response between the intensities 1210 and $1833 \mu \mathrm{mol} \mathrm{m}^{-1} \mathrm{~s}^{-1}$, above this value, it was impaired (Figure 5). 


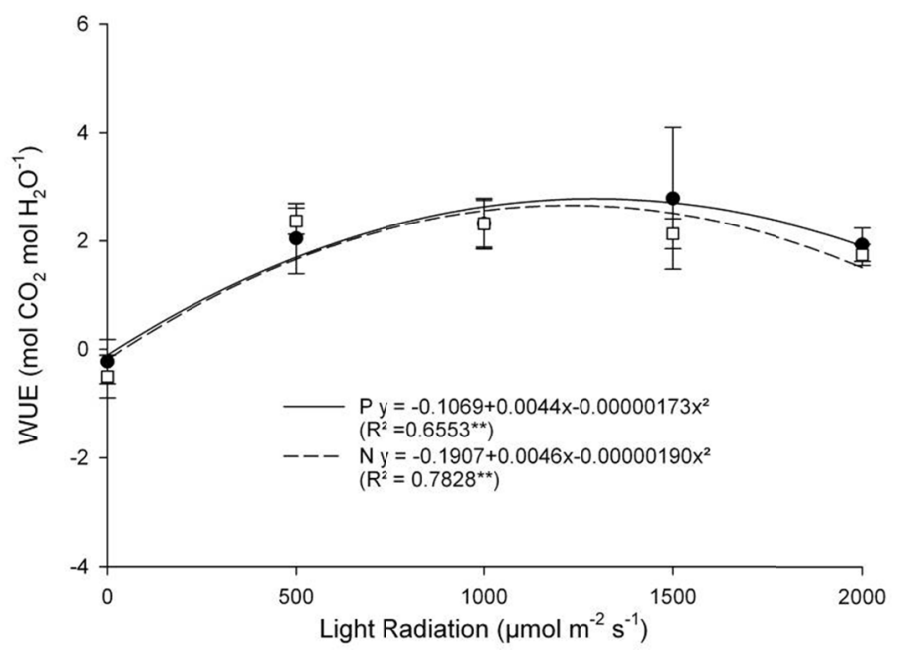

Figure 5. Water use efficiency (WUE) of soybean leaves as submitted to different light intensities

Note. $\mathrm{P}=$ Potência; $\mathrm{N}=\mathrm{NS} 6700$.

A significant negative correlation was observed in inner concentration of $\mathrm{CO}_{2}$ in substomatal chamber with the parameters transpiration (E), rate of $\mathrm{CO}_{2}$ assimilation and efficient use of water, however, a correlation with stomatal conductance (GS) were not observed (Table 4).

Table 4. $R^{2}$ values of Pearson's correlation between analyzed parameters of soybean under different light intensities

\begin{tabular}{lllll}
\hline & $\mathrm{Ci}$ & $\mathrm{E}$ & $\mathrm{GS}$ & $\mathrm{A}$ \\
\hline $\mathrm{E}$ & $-0.2538^{* *}$ & - & & \\
& $<0.0001$ & & & \\
$\mathrm{GS}$ & $-0.0895 \mathrm{Ns}$ & $0.90781^{* *}$ & - & \\
& 0.1670 & $<0.0001$ & & \\
$\mathrm{~A}$ & $-0.8365^{* *}$ & $0.65941^{* *}$ & $0.52988^{* *}$ & - \\
& $<0.0001$ & $<0.0001$ & $<0.0001$ & \\
WUE & $-0.9831^{* *}$ & $0.25136^{* *}$ & $0.133465^{*}$ & $0.86138^{* *}$ \\
& $<0.0001$ & $<0.0001$ & 0.0388 & $<0.0001$ \\
\hline
\end{tabular}

Note. Ns: $\mathrm{p} \geq 0.05 ; * 0.01 \leq \mathrm{p}<0.05 ; * * \mathrm{p}<0.01$. Rate of $\mathrm{CO}_{2}$ assimilation $\left(\mathrm{A}-\mu \mathrm{mol} \mathrm{CO} \mathrm{Cm}^{-2} \mathrm{~s}^{-1}\right)$; transpiration (E-mmol $\mathrm{H}_{2} \mathrm{O} \mathrm{m} \mathrm{s}^{-1}$ ); stomatal conductance (GS-mol $\mathrm{H}_{2} \mathrm{O} \mathrm{m}^{-2} \mathrm{~s}^{-1}$ ); inner concentration of $\mathrm{CO}_{2}$ in substomatal chamber $\left(\mathrm{Ci}-\mu \mathrm{mol} \mathrm{mol}^{-1}\right)$ and water use efficiency (WUE).

Positives correlations were observed between the parameters in which water is involved such as transpiration, rate of $\mathrm{CO}_{2}$ assimilation, stomatal conductance and efficient use o water.

\section{Discussion}

It is important to study the amount and intensity of light that are provided to plants during its initial development, because photosynthetic complex, that involves PSII and PSI, is impaired when the light intensity is above of that is necessary to plants perform its biochemical reactions of photosynthesis (Taiz \& Zeiger, 2013). That way, the most suitable intensity of light to soybean leaves perform its photosynthesis is around $1500 \mu \mathrm{mol} \mathrm{m} \mathrm{m}^{-1} \mathrm{~s}^{-1}$, so that, even the moment of the day influences in rate of $\mathrm{CO}_{2}$ assimilation (Kim et al., 2019), as Figure 1 shows.

It was expected the negative correlation between rate of $\mathrm{CO}_{2}$ assimilation and inner concentration of $\mathrm{CO}_{2}$ in stomatal chamber, as Figure 4 shows, the parameters presented opposite responses. When the rate of $\mathrm{CO}_{2}$ assimilation is lower than the inner concentration of $\mathrm{CO}_{2}$, it demonstrates that the passage of $\mathrm{CO}_{2}$ through is stomatal cleft is not occurring, that way the stomatas are closed, entailing a $\mathrm{CO}_{2}$ concentration in substomatal chambers, as Figures 1 and 4 shows. 
The opening of stomata cleft can be proved with the values found in stomata conductance (gs), as Figure 3 shows, in which the light intensity acts in stomatas. Other factors also are linked to opening and closure of stomatal clefts such as nutritional stress and herbivory (Reis et al., 2018; Reis et al., 2017; Meza-Canales et al., 2017; Shrestha et al., 2018), $\mathrm{H}_{2} \mathrm{O}$ availability in the system soil-plant-atmosphere (Bellasio et al., 2017; Li et al., 2017) and inner morphology of plants (Stewart et al., 2017; Feldman et al., 2017; Xiong et al., 2017; Rockwell \& Holbrook, 2017). These factors influences in leaves transpiration (Figure 3), that shows similar and linear responses between these two parameters, presenting a positive correlation between them.

As the gas exchanges occurs through the stomata, the plant needs hydrostatic pressure to perform the efficient use of water in the photosynthetic system, directly influencing on the initial development of different species of vegetables in the initial phase of its substrate establishment (Xiong et al., 2018; Li et al., 2017; Araújo \& Deminicis, 2009).

Seedlings of soybean positively responded under different intensities of artificial light till reach the maximum saturation point between 1400 and $1600 \mu \mathrm{mol} \mathrm{m}^{-1} \mathrm{~s}^{-1}$, which promoted a better rate of $\mathrm{CO}_{2}$ assimilation (A), concentration in the substomatic chamber (Ci) and efficient use of water (EUW). Transpiration (E) and stomata conductance (gs) presented positive linear responses by increasing the intensity of artificial light. The ideal light intensity to the use of Infra-Red Gas Analyzer-IRGA between 1400 and $1600 \mu \mathrm{mol} \mathrm{m} \mathrm{m}^{-1} \mathrm{~s}^{-1}$.

\section{References}

Araújo, S. A. C., \& Deminicis, B. B. (2006). Photoinhibition of the Photosynthesis. Brazilian Journal of Biosciences, 7(4), 463-472.

Atroch, E. M. A. C., Soares, A. M., Alvarenga, A. A., \& Castro, E. M. (2001). Growth, chlorophyll content, biomass distribution and anatomical characteristics of young plants of Bauhinia forficata link submitted to shading. Ciência e Agrotecnologia, 25(4), 853-862.

Banzatto, D. A., \& Kronka, S. N. (2013). Experimentação Agrícola (4th ed., p. 237). Funep.

Bellasio, C., Quirk, J., Buckley, T. N., \& Beerling, D. J. (2017). A dynamic hydro-mechanical and biochemical model of stomatal conductance for C4 photosynthesis. Plant Physiology, 175(1), 104-119. https://doi.org/ 10.1104/pp.17.00666

Casaroli, D., \& Lier, Q. J. (2008). Criteria for pot capacity determination. Revista Brasileira de Ciência do Solo, 32(1), 56-66.

EMBRAPA (Empresa Brasileira de Pesquisa Agropecuária). (2013). Sistema brasileiro de classificação de solos (3rd ed., p. 353). Brasília, Brazil.

Feldman, A. B., Leung, H., Baraoidan, M., Elmido-Mabilangan, A., Canicosa, I., Quick, W. P., ... Murchie, E. H. (2017). Increasing leaf vein density via mutagenesis in rice results in an enhanced rate of photosynthesis, smaller cell sizes and can reduce interveinal mesophyll cell number. Frontiers in Plant Science, 8, 1-10. https://doi.org/10.3389/fpls.2017.01883

Holt, J. S. (1995). Plant response to light: A potencial tool for weed management. Weed Science, 43, 474-482.

Kim, S., Nusinow, D. A., Sorkin, M. L., Pruneda-Paz, J., \& Wang, X. (2019). Interaction and regulation between lipid mediator phosphatidic acid and circadian clock regulators in Arabidopsis. The Plant Cell, 1-58.

Li, Y., Li, H., Li, Y., \& Zhang, S. (2017). Improving water-use efficiency by decreasing stomatal conductance and transpiration rate to maintain higher ear photosynthetic rate in drought-resistant wheat. The Crop Journal, 5(3), 231-239. https://doi.org/10.1016/j.cj.2017.01.001

Lisboa, L. A. M., Viana, R. S., Venâncio, V. G., Ribeiro, F. V., Ribeiro, I. V., Figueiredo, P. A. M., ... Batista, M. A. M. (2018). Density of Competition between Species of Urochloa sp. in Soybean Cultivation. Australian Journal of Basic and Applied Sciences, 12(9), 35-40.

Meza-Canales, I. D., Meldau, S., Zavala, J. A., \& Balduin, I. T. (2017). Herbivore perception decreases photosynthetic carbon assimilation and reduces stomatal conductance by engaging 12-oxo-phytodienoic acid, mitogen-activated protein kinase 4 and cytokinin perception. Plant, Cell \& Environment, 40(7), 1039-1056. https://doi.org/10.1111/pce.12874

Raij, B., Cantarella, H., Quaggio, J. A., \& Furlani, A. M. C. (1996). Recomendações de adubação e calagem para o Estado de São Paulo (2nd ed., p. 285). Campinas: IAC.

Reis, A. R., Barcelos, J. P. Q., Osório, C. R. W., Santos, E. F., Lisboa, L. A. M., Santini, J. M. K., ... Gratão, P. L. (2017). A glimpse into the physiological, biochemical and nutritional status of soybean plants under 
Ni-stress conditions. Environmental and Experimental Botany, 144, 76-87. https://doi.org/10.1016/ j.envexpbot.2017.10.006

Reis, A. R., Lisboa, L. A. M., Reis, H. P. G., Barcelos, J. P. Q., Santos, E. F., Santini, J. M. K., ... Lavres, J. (2018). Depicting the physiological and ultrastructural responses of soybean plants to Al stress conditions. Plant Physiology and Biochemistry, 130, 377-390. https://doi.org/10.1016/j.plaphy.2018.07.028

Rockwell, F. E., \& Holbrook, N. M. (2017). Leaf Hydraulic Architecture and Stomatal Conductance: A Functional Perspective. Plant Physiology, 174(4), 1996-2007. https://doi.org/10.1104/pp.17.00303

Shrestha, A., Buckley, T. N., Lockhart, E. L., \& Barbour, M. M. (2018). The response of mesophyll conductance to short- and long-term environmental conditions in chickpea genotypes. Aob Plants, 11(1), 1-16.

Silva, F. A. S., \& Azevedo, C. A. V. (2016). The Assistat Software Version 7.7 and its use in the analysis of experimental data. African Journal Agriculture Resarch, 11(39), 3733-3740. https://doi.org/10.5897/ AJAR2016.11522

Singh, S. K., \& Reddy, V. R. (2018). Co-regulation of photosynthetic processes under potassium deficiency across $\mathrm{CO}_{2}$ levels in soybean: mechanisms of limitations and adaptations. Photosynthesis Research, 137(2), 183-200. https://doi.org/10.1007/s11120-018-0490-3

Stewart, J. J., Polutchko, S. K., Adams Iii, W. W., Cohu, C. M., Coleman, A., Wenzl, C. A., \& Demmig-Adams, B. (2017). Light, temperature and tocopherol status influence foliar vascular anatomy and leaf function in Arabidopsis thaliana. Physiologia Plantarum, 160(1), 98-110. https://doi.org/10.1111/ppl.12543

Taiz, L., \& Zeiger, E. (2013). Fisiologia vegetal (5th ed., p. 918). Porto Alegre: Artmed.

Teixeira, M. C., Vieira, T. O., Almeida, T. C. M., \& Vitória, A. P. (2015). Photoinhibition in Atlantic Forest native species: Short-term acclimative responses to high irradiance. Theoretical and Experimental Plant Physiology, 27(3), 183-189. https://doi.org/10.1007/s40626-015-0043-5

Vieira, T. O., Degli-Esposti, M. S. O., Souza, G. M., Rabelo, G. R., \& Vitória, A. P. (2015). Photoacclimation capacity in seedling and sapling of Siparuna guianensis (Siparunaeae): Response to irradiance gradient in tropical forest. Photosynthetica, 53(1), 11-22. https://doi.org/10.1007/s11099-015-0073-x

Yang, F., Yuanfang F., Xiaoling, W., Yajiao, C., Qinlin, L., Lingyang, F., ... Wenyu, Y. (2018). Auxin-to-Gibberellin Ratio as a Signal for Light Intensity and Quality in Regulating Soybean Growth and Matter Partitioning. Frontiers in Plant Science, 9, 1-13. https://doi.org/10.3389/fpls.2018.00056

Xiong, D., Douthe, C., \& Flexas, J. (2018). Differential coordination of stomatal conductance, mesophyll conductance, and leaf hydraulic conductance in response to changing light across species. Plant, Cell \& Environment, 41(2), 436-450. https://doi.org/10.1111/pce.13111

\section{Copyrights}

Copyright for this article is retained by the author(s), with first publication rights granted to the journal.

This is an open-access article distributed under the terms and conditions of the Creative Commons Attribution license (http://creativecommons.org/licenses/by/4.0/). 